\title{
New Disease Reports \\ First report of a phytoplasma associated with witches' broom symptoms in Waltheria indica in Brazil
}

M.S. Alves, G.M. Ribeiro, A.N. Souza and C.M. Carvalho*

Department of Phytopathology, Universidade Federal de Viçosa, Avenida PH Rolfs s/n, 36570-900, Viçosa, Minas Gerais, Brazil

*E-mail: claudine.carvalho@ufv.br

Received: 13 Feb 2017. Published: 18 May 2017.

Waltheria indica (Malvaceae) is a short-lived shrub, native to the neotropics but with a pantropical distribution, which is frequently used for medicinal purposes (Zongo et al., 2013). In January 2016, W. indica plants located in a coastal area of Vila Velha (state of Espirito Santo, Brazil, S20 $31^{\prime} 42.51^{\prime \prime}$, W40 22 '24.1356") were found exhibiting symptoms of witches' broom and yellowing (Fig. 1).

Leaf samples were collected from branches of three symptom-bearing and two symptomless $W$. indica plants. Total DNA was extracted from each sample and subjected to nested polymerase chain reaction (nPCR) amplification of the phytoplasma 16S rRNA gene with primers P1/P7 (Deng \& Hiruki, 1991) and R16F2n/R2 (Gundersen \& Lee, 1996). Amplicons of the expected size $(1.2 \mathrm{~kb})$ were obtained from all plants showing symptoms but not from symptomless plants. The amplicons were purified using an Illustra GFX PCR DNA and Gel Band Purification Kit (GE Healthcare, UK), cloned using the pGEM $^{\circledR}$-T Easy Vector System I (Promega, USA) and sequenced by Macrogen Inc. (Korea). BLAST searches confirmed that the consensus $16 \mathrm{~S}$ rDNA sequence of the Waltheria indica witches' broom phytoplasma (WIWB) (GenBank Accession No. KX691443) shared $99.4 \%$ sequence identity with those of 'Candidatus Phytoplasma asteris' (16SrI group) species (e.g. HM067755, KP864664, AF222066). The WIWB phytoplasma was preliminary classified as a member of the 16SrI-S subgroup, with a similarity coefficient of 0.99 based on RFLP analysis when compared to $16 \mathrm{SrI}$ phytoplasmas using $i$ PhyClassifier (Zhao et al., 2013). Phylogenetic analysis using the neighbour-joining method in MEGA7 software (www.megasoftware.net/) supported the sequencing and iPhyClassifier results (Fig. 2).

The occurrence of phytoplasmas in $W$. indica has been previously reported in Brazil and Australia (Kitajima \& Costa, 1971; Schneider et al., 1999), associated with phytoplasmas of group $16 \mathrm{SrII}$ ' $\mathrm{Ca}$. P. aurantifolia'. To our knowledge, this is the first report of a member of 16SrI phytoplasma

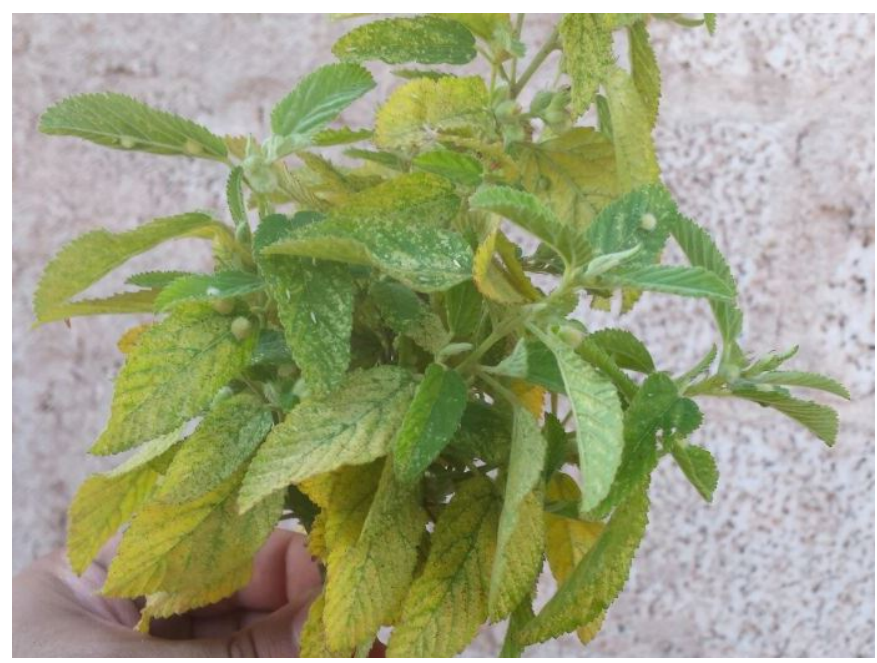

Figure 1 associated with $W$. indica plants in Brazil, which may pose a threat to other nearby plant species.

\section{Acknowledgements}

The authors would like to thank Vale S.A. for financial support. CMC is in receipt of a Conselho Nacional de Desenvolvimento Técnico e Científico (CNPq) productivity grant.

\section{References}

Deng S, Hiruki C, 1991. Amplification of 16S rRNA genes from culturable and nonculturable mollicutes. Journal of Microbiological Methods 14, 53-61. http://dx.doi.org/10.1016/0167-7012(91)90007-D

Gundersen DE, Lee IM, 1996. Ultrasensitive detection of phytoplasmas by nested-PCR assays using two universal primer sets. Phytopathologia Mediterranea 35, 144-151.

Kitajima EW, Costa AS, 1971. Corpúsculos do tipo micoplasma associados a diversas moléstias de plantas, do grupo amarelo, no estado de São Paulo. Ciência e Cultura (São Paulo) 23, 285-291.

Schneider B, Padovan A, De La Rue S, Eichner R, Davis R, Bernuetz A, Gibb K,1999. Detection and differentiation of phytoplasmas in Australia: an update. Australian Journal of Agricultural Research 50, 333-342. http://dx.doi.org/10.1071/A98106

Zhao Y, Wei W, Lee I-M, Shao J, Suo X, Davis RE, 2013. The $i$ PhyClassifier, an interactive online tool for phytoplasma classification and taxonomic assignment. Methods in Molecular Biology 938, 329-338. http://dx.doi.org/10.1007/978-1-62703-089-2 28

Zongo F, Ribuot C, Boumendjel A, Guissou I, 2013. Botany, traditional uses, phytochemistry and pharmacology of Waltheria indica L. (syn. Waltheria americana): a review. Journal of Ethnopharmacology 148, 14-26. http://dx.doi.org/10.1016/j.jep.2013.03.080

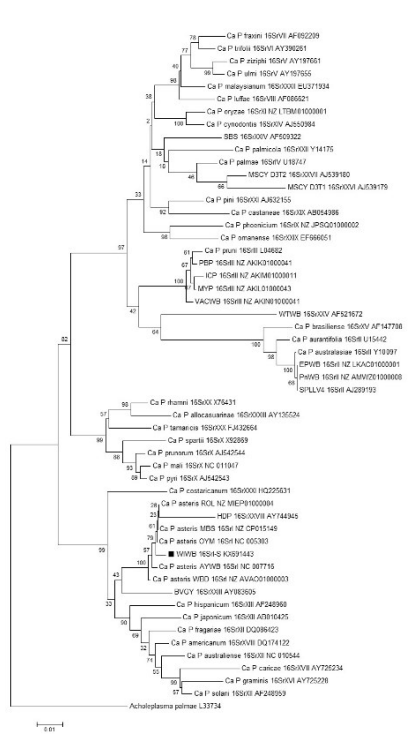

Figure 2

To cite this report: Alves MS, Ribeiro GM, Souza AN, Carvalho CM, 2017. First report of a phytoplasma associated with witches' broom symptoms in Waltheria indica in Brazil. New Disease Reports 35, 28. http://dx.doi.org/10.5197/j.2044-0588.2017.035.028 